\title{
Residual decontamination chemical agents negatively affect adhesion and proliferation of osteoblast-like cells on implant surface
}

\author{
Ísis de Fátima Balderrama ${ }^{1,2^{*}}$, Matheus Völz Cardoso ${ }^{2}$, Vitor Toledo Stuani ${ }^{2}$, Rodrigo Cardoso Oliveira ${ }^{3}$, \\ Adriana Arruda Matos ${ }^{3}$, Sebastião Luiz Aguiar Greghi ${ }^{2}$ and Adriana Campos Passanezi Sant'Ana²
}

\begin{abstract}
Purpose: To investigate the influence of implant surface decontaminated and uncontaminated on osteoblast-like cell adhesion and proliferation

Materials and methods: Commercially available implants of different brands and surface characteristics were selected: Biomet $3 i^{\oplus}$ Nanotite (NT) and Osseotite (OT), Straumann ${ }^{\oplus}$ SLActive (SLA), and Neodent ${ }^{\oplus}$ Acqua Drive (ACQ) and Neoporos Drive CM (CM). Physical and chemical properties of the implants were investigated by scanning electron microscopy (SEM), energy dispersive X-ray spectroscopy (EDS), and wettability analysis (WETT). Implants were previously contaminated with Aggregatibacter actinomycetemcomitans strains; after that, samples were decontaminated by different chemical methods. Decontaminated (test group; $n=15 /$ type of implant) and uncontaminated (control group; $n=5 /$ type of implant) samples were analyzed according to the number of human osteoblastic osteosarcoma cells (Saos-2) adhered on the implant surface after $24 \mathrm{~h}$ and $72 \mathrm{~h}$ in SEM images.

Results: ACQ was found to be highly hydrophilic, and NT was the most hydrophobic implant. Increased variation of Saos-2 cell adhesion and proliferation were observed on all test and control groups. Controversially, at the proliferation analysis in $72 \mathrm{~h}, \mathrm{CM}$ implant was the only implant that showed no significant difference between test and group ( $p=0.2833$; Tukey's multiple comparisons test). NT implants showed the greater value of cell proliferation when compared with all types of implant surface ( $p=0.0002$; Tukey's multiple comparisons test).

Conclusions: These findings suggest that decontaminated surfaces were able to impair the counting of osteoblastlike cell adhesion and proliferation.
\end{abstract}

Keywords: Dental implants, Decontamination, Osteoblast-like cells, Implant surface, Peri-implantitis

\section{Introduction}

Osseointegration is defined as a direct contact between vital bone and implant surface at optical microscopy level [1] and describes a rigid fixation of an alloplastic material in the bone, in an asymptomatic clinical situation and functional load [2]. The literature demonstrates five

\footnotetext{
* Correspondence: if.balderrama@unesp.br

'Department of Diagnosis and Surgery, Araraquara School of Dentistry, Sao

Paulo State University, Araraquara, Sao Paulo, Brazil

2Department of Prosthodontics and Periodontics, Bauru School of Dentistry,

University of Sao Paulo, Bauru, Sao Paulo, Brazil

Full list of author information is available at the end of the article
}

factors that are essential for osseointegration, such as implant design, implant material, surface properties, bone quality, and surgical technique [3]. Among surface properties, topography, chemistry, charge, and wettability are key determinants for osseointegration [4]. Changes on implant surface properties, such as an increase in roughness, were proposed to lead to a better clinical and histological result [5], influencing cell behavior [6] and biofilm formation [7].

Peri-implant microbiota has a similar composition to the one observed at the gingival sulcus of adjacent teeth [8-10]. Just like in natural teeth, the development of biofilm induces biological responses of hard and soft tissue 
around implants, resulting in pocket deepening, bleeding on probing, exudation, bone loss, and clinical mobility, impairing the success of implant therapy $[8,11]$.

The colonization, structure, and composition of the biofilm on implant surfaces is influenced by its surface roughness, chemical composition, hydrophobic properties, surface electrical charge, and energy [7, 12]. Modifications in micro- and nano-topography of dental implants were proposed to increase bone-to-implant contact, but biofilm accumulation in rougher surfaces is accelerated when implant threads are exposed to the oral cavity $[12,13]$, which make these areas more difficult to decontaminate [13]. On the other hand, moderate rough implants show higher rates of reosseointegration when compared to machined ones [14].

Considering that decontamination of rough implant surfaces is a challenge in the treatment of peri-implant diseases, it is essential to provide adequate conditions to obtain re-osseointegration [15-17] by removing all the contaminant load, since bacterial remnants impair reosseointegration and leads to peri-implantitis recurrence [18]. Decontamination and/or detoxification of implant surfaces can be performed by mechanical and chemical methods [17-20]. There is no consensus in literature on the best protocol to decontaminate implant surfaces [21]. Decontamination with different solutions was unable to completely decontaminate implant surfaces [22, 23 ] and could induce changes in the chemical and physical properties of implant surfaces [24], with partial reosseointegration being reported in animals [22].

The aim of this study is to investigate the behavior of osteoblastic cells in different moderate rough implants and compare the results of different pristine and decontaminated surfaces.

\section{Material and methods}

\section{Experimental design}

Five types of implants with different macro and microstructure were acquired in the market and are described in Table 1 and Fig. 1.

\section{Surface chemical composition}

The chemical composition of each implant surface $(n=$ $1 /$ type of implant) was investigated at cervical, central, and apical regions by energy dispersive $\mathrm{X}$-ray detector (EDS, INCA $x$-act, Oxford) to analyze the percentage of chemical atomic element at the Anelasticity and Biomaterials Laboratory of Sao Paulo State University (Bauru, Sao Paulo, Brazil).

\section{Wettability (sessile-drop contact angle measurements)}

Wettability properties were investigated on implant surface ( $n=1$ /type of implant) at the Chemical-Physical Department of São Paulo State University (Araraquara, Sao Paulo, Brazil). Samples were stabilized in acrylic resin models and analyzed only in the mid-third of each implant. Wettability was analyzed at room temperature, with 75\% air relative humidity, at the Contact Angle System (video-based Dataphysics, OCA, 15model). Average values of the right and left angles of each sample were determined. Standardized parameters were adjusted in a volume water of $1.000 \mu \mathrm{l}$, a medium probe, and a wettability time (waterfall) of $10 \mathrm{~s}$. The right and left contact angle (CA) were defined by Young La Place equation (Fig. 2).

\section{Contamination of implants with strains of $A a$ (ATCC 29523)}

The protocol of contamination was based on Freire et al. [25]. An amount of $20 \mu \mathrm{l}$ of A. actinomycetemcomitans (Aa) was prepared, and after 2 days of incubation, the colony was collected and transferred in a tube with $5 \mathrm{~mL}$ of broth culture medium BHI (Brain Heart Infusion Agar, Acumedia, Neogen Corporation, MI, USA) at $37^{\circ} \mathrm{C}$ for a period of 4 days. Implants were contaminated with a bacterial concentration of $1.5 \times 10^{8} \mathrm{CFU}$ in $2 \mathrm{~mL}$ of broth culture medium per well.

Table 1 Characteristics of dental implants evaluated according to manufacturer

\begin{tabular}{|c|c|c|c|c|}
\hline Manufacturer & $\begin{array}{l}\text { Implant } \\
\text { type }\end{array}$ & Surface treatment & Macrogeometry & $\begin{array}{l}\text { External } \\
\text { dimensions }(\varnothing \times L)\end{array}$ \\
\hline 1.Biomet $3 i^{\circledR}$ (USA) & Nanotite & $\begin{array}{l}\text { Dual-acid-etched and nanometer scale crystals of calcium } \\
\text { phosphate }\end{array}$ & $\begin{array}{l}\text { Parallel walled } \\
\text { Tapered }\end{array}$ & $4.0 \times 10 \mathrm{~mm}$ \\
\hline 2.Biomet $3 i^{\circledR}$ (USA) & Osseotite & $\begin{array}{l}\text { Dual-acid-etched, sandblasted and processed with nitric, } \\
\text { hydrochloric and sulfuric acids }\end{array}$ & $\begin{array}{l}\text { Parallel walled } \\
\text { Certain } \\
\text { Tapered }\end{array}$ & $4.0 \times 10 \mathrm{~mm}$ \\
\hline $\begin{array}{l}\text { 3. Straumann }{ }^{\oplus} \\
\text { (Switzerland) }\end{array}$ & Bone level & $\begin{array}{l}\text { SLActive, chemically modified surface of sandblasted, large- } \\
\text { grit, acid-etched }\end{array}$ & $\begin{array}{l}\text { Hybrid tapered, platform } \\
\text { switch }\end{array}$ & $4.1 \times 10 \mathrm{~mm}$ \\
\hline 4. Neodent ${ }^{\oplus}$ (Brazil) & $\begin{array}{l}\text { Drive CM } \\
\text { Acqua }\end{array}$ & $\begin{array}{l}\text { Acqua, sandblasted, acid-etched and immersed in } 0.9 \% \text { so- } \\
\text { dium chloride }\end{array}$ & $\begin{array}{l}\text { Conical central, Cone } \\
\text { Morse connection }\end{array}$ & $43 \times 10 \mathrm{~mm}$ \\
\hline 5.Neodent ${ }^{\oplus}$ (Brazil) & $\begin{array}{l}\text { Drive CM } \\
\text { Neoporos }\end{array}$ & Neoporos, sandblasted with acid-etched & $\begin{array}{l}\text { Conical central, Cone } \\
\text { Morse connection }\end{array}$ & $4.3 \times 10 \mathrm{~mm}$ \\
\hline
\end{tabular}



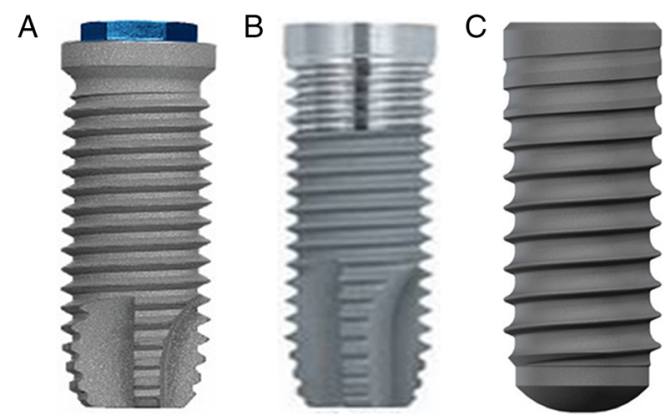

$\mathrm{D}$

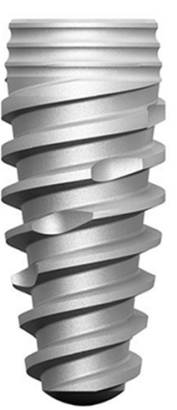

E

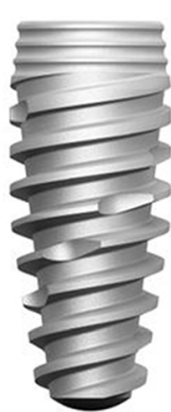

$\mathrm{F}$

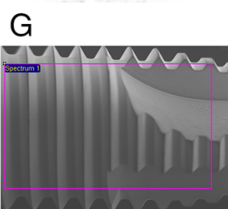

$\mathrm{H}$

।
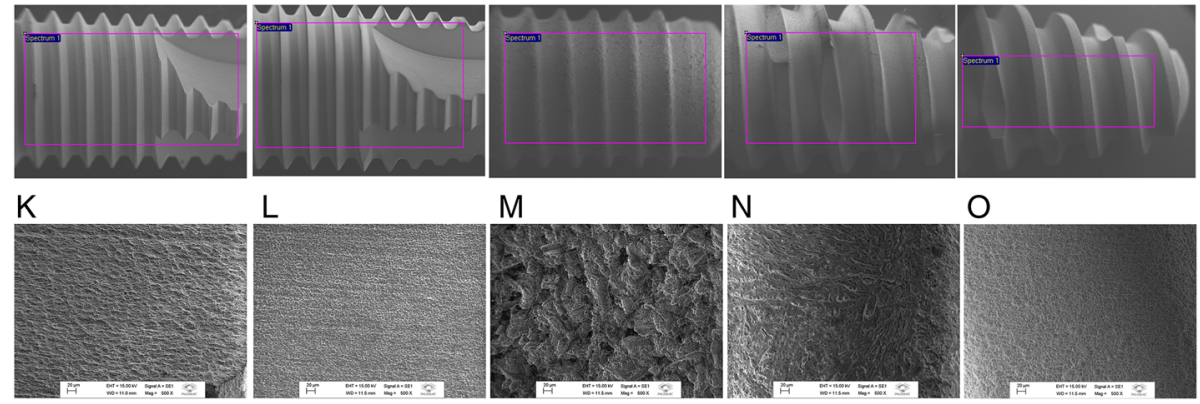

$\mathrm{N}$

$\mathrm{O}$

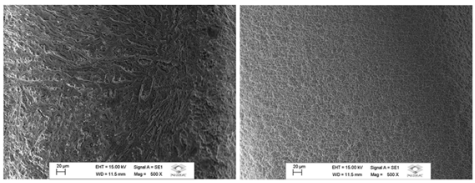

Fig. 1 General features and macrogeometry of each model of dental implant evaluated (Macrogeometry and SEM images; $\times 500$ magnification).

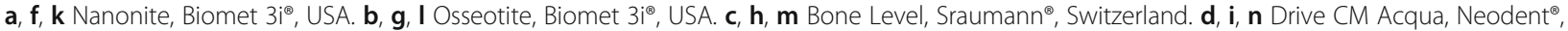
Brazil. e, $\mathbf{j}$, o Drive CM Neoporos, Neodent ${ }^{\oplus}$, Brazil
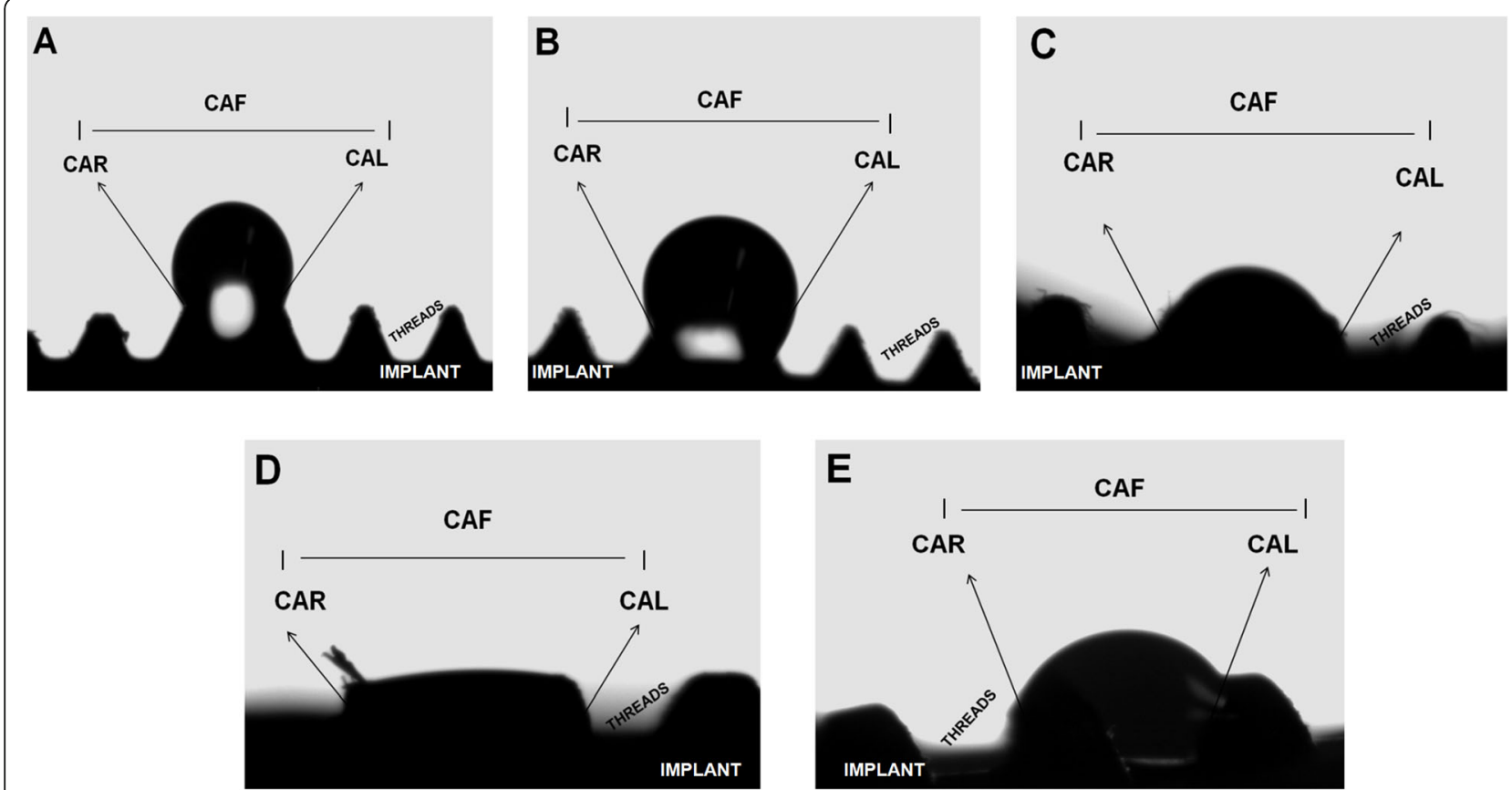

Fig. 2 Wettabilty analysis. CAR, contact angle right side; CAL, contact angle left side; CAF, contact angle final; a Nanotite. b Osseotite. c SLActive. d Acqua. e Cone Morse Neoporos 


\section{Decontamination of implant surfaces}

After the days of contamination process, the decontamination of implant surface was performed inside a laminar flow hood. The groups of different protocols for decontamination were prescribed for the sample $(n=6$ / type of implant):

1) Immersion in chlorhexidine $0.12 \%$ for $3 \mathrm{~min}$;

2) Sequential immersion in EDTA 24\% for 3 min and citric acid $10 \%$ for 3 min;

3) Antimicrobial photodynamic therapy (methylene blue $100 \mu \mathrm{g} / \mathrm{ml}$ and Diode LASER, Therapy XT [DMC, Sao Carlos, Sao Paulo, Brazil] for $3 \mathrm{~min}$ ).

In the final stage, all implants were rinsed with saline solution for $1 \mathrm{~min}$. The experimental group consists of the sum of all decontaminated samples, and the control group consists of implant surface uncontaminated $(n=$ $1 /$ type of implant).

\section{Osteoblast-like cell adhesion and proliferation}

Pre-existing human primary osteogenic sarcoma (Saos2) cells (ATCC HTB85) were gently provided by the Department of Oral and Maxillofacial Surgery and Periodontics of Ribeirao Preto School of Dentistry-USP. Cells were cultivated in 15\% McCoys' culture medium containing $2 \mathrm{mM}$ glutamine and $10 \%$ fetal bovine serum in humid atmosphere containing $5 \% \mathrm{CO}_{2}$ at $37^{\circ} \mathrm{C}$. Culture medium was replaced every other day. Upon confluence, cells were detached by enzymatic methods $(0.2 \%$ trypsin) and transferred to progressively larger tissue flasks (Sigma-Aldrich, Sao Paulo, Brazil). Saos-2 cells (5 $\times 10^{4}$ in $220 \mu \mathrm{L}$ of culture medium) were plated on pristine implants (control; $n=5 /$ type of implant) and on decontaminated implants (test; $n=15$ /type of implant). For this, the samples were positioned in 24-well cell culture plates containing culture medium 15\% McCoy's 5A $+2 \mathrm{mM}$ glutamine $+10 \%$ fetal bovine serum (medium $=$ $50 \mathrm{ml}, 42.5$ McCoys more 7.5 fetal bovine saline), and were maintained in an incubator for wet cell culture atmosphere containing $5 \% \mathrm{CO}_{2}$ at $37^{\circ} \mathrm{C}$ (Fig. 3). After $24 \mathrm{~h}$ and $72 \mathrm{~h}$, the samples were fixed with Karnovsky solution (6\% glutaraldehyde and $4 \%$ paraformaldehyde in $0.2 \mathrm{M}$ cacodylate buffer) for $2 \mathrm{~h}$. After two washes in 0.1 $\mathrm{M}$ cacodylate buffer for $15 \mathrm{~min}$, the specimens were fixed with $2 \%$ osmium tetroxide in cacodylate buffer at $4{ }^{\circ} \mathrm{C}$ for $2 \mathrm{~h}$ and dehydrated with solutions of alcohol $30-70 \%$. After gradually increasing concentration gradient, the specimens were embedded in 100\% hexamethyldisilazane and dried at room temperature for $24 \mathrm{~h}$. After that, the specimens were coated with gold (Q150R E Plus, UK) for $20 \mathrm{~s}$ with a density of $9.32 \mathrm{~g} / \mathrm{m}^{3}$. Three photomicrographs corresponding to the cervical, central, and apical thirds of each implant investigated were acquired at $\times 500$ magnification (AFORE, JEOL, JSM-6610, Japan). The adhesion of Saos-2 cells on implant valleys and flanks were analyzed in combination. Cell counting was performed using the ImageJ software $(\mathrm{NIH}, \mathrm{Be}-$ thesda, USA), according to the plugin Counting Cells (University of Chicago, USA). Briefly, SEM images were converted to 32 bits; the threshold tool was selected to subtract background and analyze particles, resulting in the total and percentage area covered by cells.

\section{Statistical analysis}

Statistical analysis was performed at GraphPad Prism 7.0 for Mac, adopting a 5\% significance level at all tests. Comparisons in wettability analysis were performed by Kruskal-Wallis post hoc Dunn. The number of cells adhered to implant surfaces after $24 \mathrm{~h}$ and $72 \mathrm{~h}$ in experimental and control groups were analyzed between and within groups by ANOVA post hoc Tukey's multiple comparisons test.

\section{Results}

Surface chemical composition

The chemical composition in atomic percentage (atomic\%) of each implant is demonstrated in Fig. 4. NT and $\mathrm{CM}$ implants were composed of titanium only (100\%); OT implant showed the presence of titanium
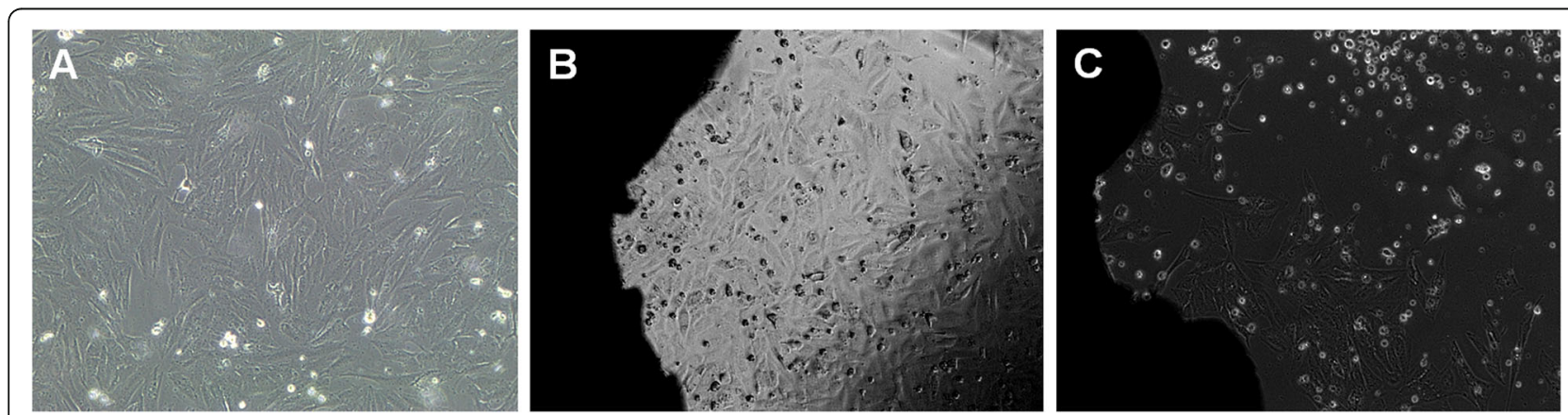

Fig. 3 Human primary osteogenic sarcoma (Saos-2) cells $\left(5 \times 10^{4}\right.$ cells). a Saos-2 cells before plating; b $24 \mathrm{~h}$ of Saos-2 cells on dental implant surface; $\mathbf{c} 72 \mathrm{~h}$ of Saos-2 cells on dental implant surface 


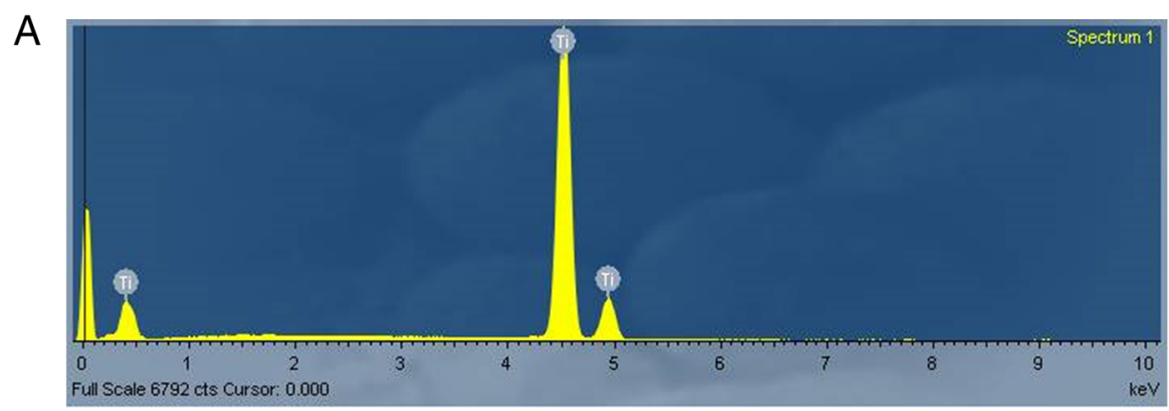

B

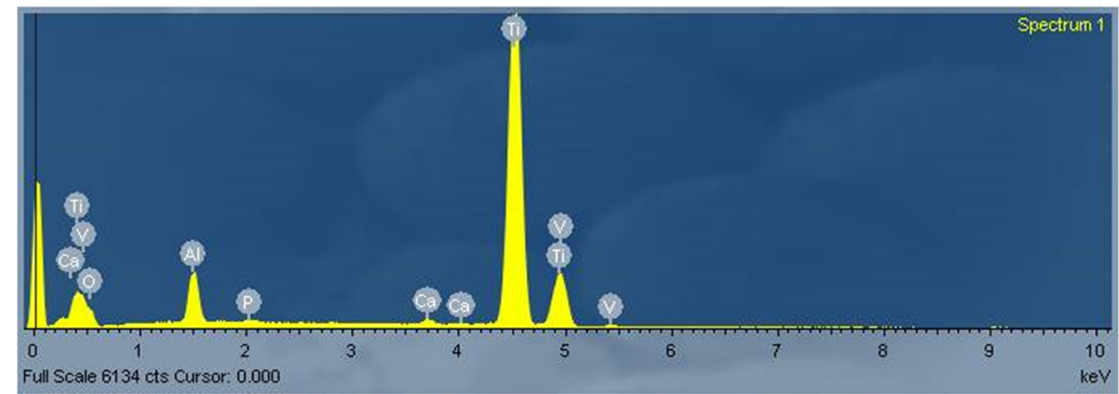

C

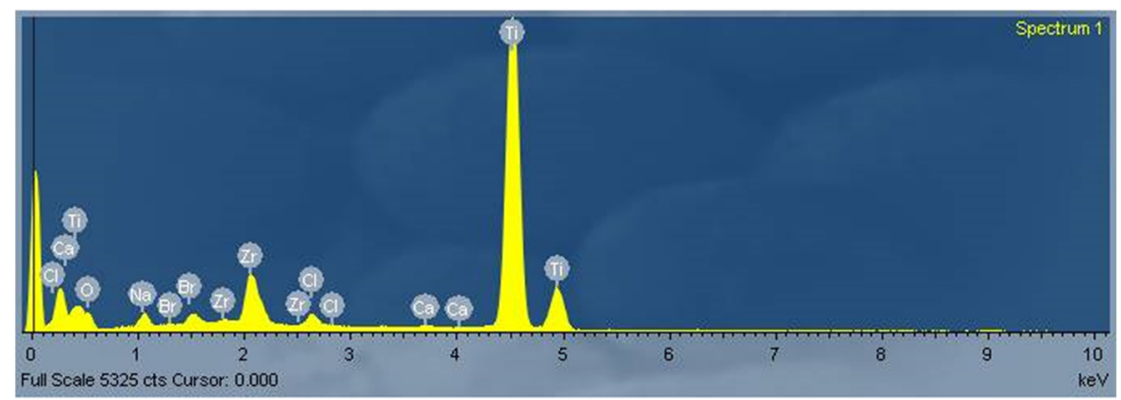

D

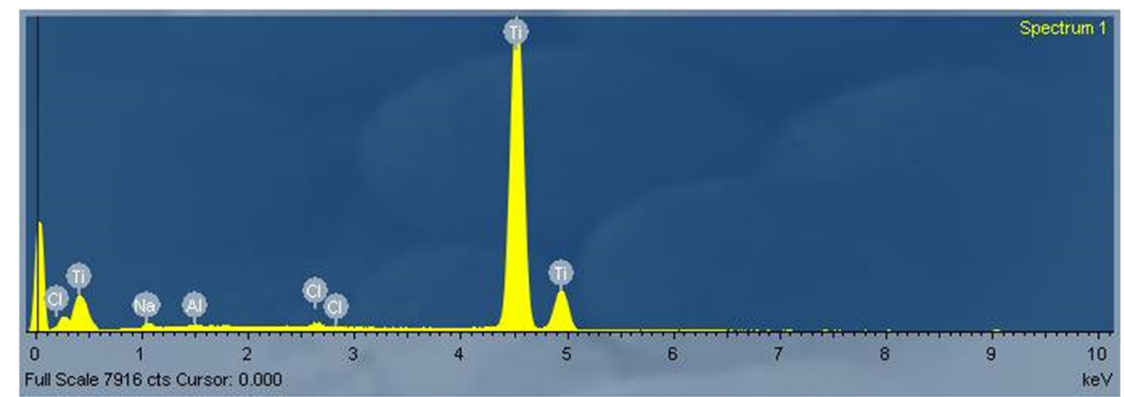

E

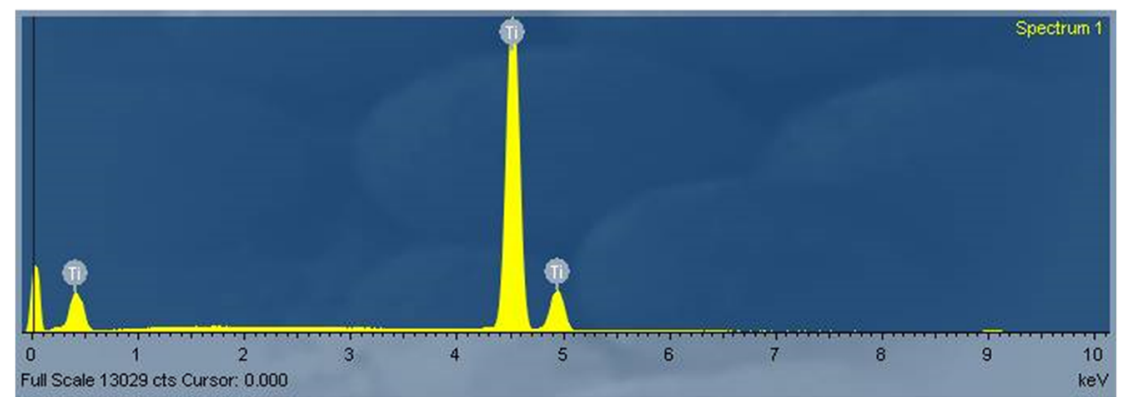

Fig. 4 Spectrum of EDS for the area analyzed. Chemical composition of titanium with different surface treatment, note the high peaks of titanium element (a, b, c, d, and e). a Nanotite. b Osseotite. c SLActive. $\mathbf{d}$ Acqua. e Cone Morse 
Table 2 Wettability results

\begin{tabular}{llll}
\hline & CAR & CAL & CAF \\
\hline NT & $126.6^{\circ}$ & $126.3^{\circ}$ & $131.1^{1^{* *}}$ \\
OT & $115.4^{\circ}$ & $117.2^{\circ}$ & $110.9^{\circ}$ \\
SLA & $55.9^{\circ}$ & $60.0^{\circ}$ & $40.6^{\circ}$ \\
ACQ & $<5^{\circ}$ & $<5^{\circ}$ & $<5^{\circ *}$ \\
CM & $76.3^{\circ}$ & $73.6^{\circ}$ & $79.4^{\circ}$ \\
\hline
\end{tabular}

*Significant differences $(p<0.05)$

Kruskal-Wallis $p<0.0001$; significant differences $(p<0.05)$ between groups NT and ACQ (mean values)

(65.86\%), oxygen (23.92\%), aluminum (6.21\%), vanadium (2.92\%), calcium $(0.69 \%)$, and phosphorus $(0.40 \%)$; SLA implant showed the presence of titanium (66.38\%), oxygen $(22.73 \%)$, zirconium $(5.12 \%)$, sodium $(3.11 \%)$, bromine $(0.77 \%)$, chlorum $(1.60 \%)$, and calcium $(0.30 \%)$; and ACQ implant showed the presence of titanium (97.34\%), sodium (1.54\%), chlorum (0.78\%), and aluminum (0.33\%).

\section{Wettability analysis}

The sessile-drop contact angle analysis showed that ACQ exhibited the most hydrophilic behavior, while NT and OT exhibited more hydrophobic responses (Table 2). Significant differences $(p<0.0001$; KruskalWallis) were found between NT (hydrophobic) and ACQ (hydrophilic).

\section{Adhesion and proliferation of Saos- 2 cells in uncontaminated and decontaminated sites}

All decontaminated implants showed less cells adhered at surfaces after $24 \mathrm{~h}$ and $72 \mathrm{~h}$ when compared to the respective uncontaminated sites (control group) (Table 3). The results of cell adhesion on implant surface at $24 \mathrm{~h}$ (Fig. 5) after decontamination protocols (test group) showed lower values when compared to the control group; however, only CM implants showed statistic significant difference between test and control group ( $p=$ 0.0498; Tukey's multiple comparisons test) (Table 3).

The results of cell proliferation on implant surface at $72 \mathrm{~h}$ (Fig. 5) after decontamination protocols (test group) also showed lower values when compared to pristine implants (control group). No differences were found between intergroup analysis in the test group $(p>0.05$; Tukey's multiple comparisons test). NT implants showed the higher value at cell proliferation for the control group, showing statistic significant difference when compared to all other types ( $p=0.0002$; Tukey's multiple comparisons test) (Table 3). Therefore, when comparing the control with the test group, only CM showed no significant difference $(p=0.2833)$.

\section{Discussion}

In the past few years, the prevalence of mucositis and peri-implantitis has increased, varying from 19 to $65 \%$ and from 1 to 47\%, respectively [26]. Plaque accumulation at implant surfaces triggers an inflammatory response that leads to the development of mucositis or peri-implantitis [27]. In this study, we have investigated surface properties of different implants acquired in the market, including chemical composition and wettability analysis. Additionally, we have also investigated the effects of chemical surface decontamination on the adhesion and proliferation of osteoblast-like cells. Implant surface properties are influenced not only by microtopography or nanotopography, but also by macrotopography. Most in vitro studies investigating the effects of decontamination methods of implant surfaces are performed in titanium disks [7, 12, 19, 21, 24, 28-33] which do not reproduce the macro- and microtopography characteristics of implants. For these reasons, in this study, we aimed to investigate the impact of chemical decontamination at cell adhesion and proliferation in five different dental implants of different brands that previously received unique surface treatments and are considered the most commercially available in the world.

Rosa et al. [34] have also investigated implants from different batches and companies, totalizing 3 implants per group, and found differences from batches of the same company in two types of Brazilian implants, while the remaining samples were more uniform. Considering

Table 3 Cell adhesion ( $24 \mathrm{~h}$ ) and proliferation (72 h) on implant surfaces (mean \pm SD)

\begin{tabular}{|c|c|c|c|c|c|c|c|c|c|c|c|c|c|c|c|}
\hline & \multicolumn{3}{|l|}{ NT } & \multicolumn{3}{|l|}{ OT } & \multicolumn{3}{|l|}{ SLA } & \multicolumn{3}{|l|}{$A C Q$} & \multicolumn{3}{|l|}{$\mathrm{CM}$} \\
\hline & Control & Test & $p$ & Control & Test & $p$ & Control & Test & $p$ & Control & Test & $p$ & Control & Test & $p$ \\
\hline $\begin{array}{l}24 \\
h\end{array}$ & $\begin{array}{l}4535.3 \pm \\
2919.5 a, c\end{array}$ & $\begin{array}{r}1329.8 \pm \\
205.7 a, b\end{array}$ & $\begin{array}{l}> \\
0.9999\end{array}$ & $\begin{array}{l}5140.0 \\
\pm 929.8 \mathrm{c}\end{array}$ & $\begin{array}{l}2468.1 \pm \\
658.7 a, c, \\
b\end{array}$ & 0.3205 & $\begin{array}{l}3538.3 \pm \\
2251.9 a, c \\
b\end{array}$ & $\begin{array}{l}864.6 \pm \\
445.0 a \\
b\end{array}$ & 0.3197 & $\begin{array}{l}4109.6 \pm \\
843.1 a, c \\
b\end{array}$ & $\begin{array}{l}1688.6 \\
\pm \\
326.2 a, b\end{array}$ & 0.4444 & $\begin{array}{l}4519.6 \\
\pm \\
559.2 \mathrm{a}, \mathrm{c}\end{array}$ & $\begin{array}{l}746.2 \pm \\
863.2 \mathrm{~b}\end{array}$ & 0.0498 \\
\hline $\begin{array}{l}72 \\
h\end{array}$ & $\begin{array}{l}14,368.7 \\
\pm 3481.8 \mathrm{a}\end{array}$ & $\begin{array}{l}2160.7 \pm \\
2912.0 b\end{array}$ & $\begin{array}{l}< \\
0.0001\end{array}$ & $\begin{array}{l}7694.3 \\
\pm 655.3 \\
c\end{array}$ & $\begin{array}{l}1446.8 \pm \\
725.9 b\end{array}$ & 0.0026 & $\begin{array}{l}7165.6 \pm \\
122.0 \mathrm{c}\end{array}$ & $\begin{array}{l}642.0 \pm \\
190.6 \mathrm{~b}\end{array}$ & 0.0016 & $\begin{array}{l}8831.3 \pm \\
402.5 c\end{array}$ & $\begin{array}{l}2669.7 \\
\pm 562.5 \\
b\end{array}$ & 0.003 & $\begin{array}{l}6558.6 \\
\pm \\
1285.3 \mathrm{c}\end{array}$ & $\begin{array}{l}3267.3 \\
\pm 689.7 \\
b\end{array}$ & 0.2833 \\
\hline$p$ & 0.02 & 0.6479 & & 0.0177 & 0.1455 & & 0.0495 & 0.4703 & & 0.0009 & 0.0592 & & 0.0654 & 0.0168 & \\
\hline
\end{tabular}

Tukey's multiple comparisons test; post hoc Tukey; different letters in same line represent significant differences between groups

$C$ control (uncontaminated), $T$ test (decontaminated)

*Significant differences $(p<0.05)$; Tukey's multiple comparisons test 


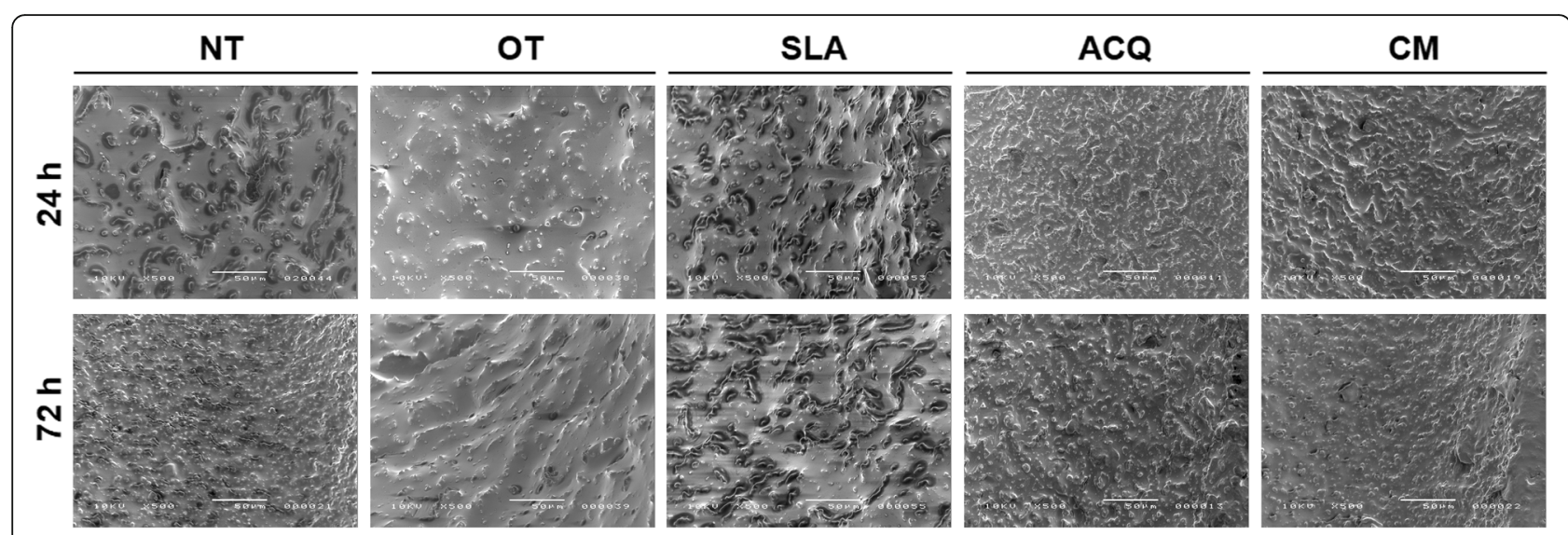

Fig. 5 SEM photomicrographs of Saos-2 cell adhesion and proliferation. SEM images of Saos-2 cells on NT, OT, SLA, ACQ, and CM dental implant surfaces after 24 and $72 \mathrm{~h}$, adhesion and proliferation respectively ( $\times 500$ magnification)

that, we have used 6 samples of each implant, minimizing the risk of bias.

Microbial colonization around implants follows a similar course than natural teeth, with a shift in microbial composition as disease develops [35]. A study [36] showed that the prevalence of periodontal pathogens was similar among individuals with periodontitis and peri-implantitis, independent from health condition. While the prevalence and levels of $P$. gingivalis and $F$. nucleatum were positively associated with periodontitis, but not with peri-implantitis, $A$. actinomycetemcomitans was positively associated with both periodontitis and peri-implantitis. Different studies showed that A. actinomycetemcomitans is consistently found in periimplantitis [10, 36-38], being able to infect the abutment-implant interface $[9,10]$. In this study, a strain of $A$. actinomycetemcomitans was used to contaminate implant surfaces, considering that this species is able to induce biofilm formation in smooth and rough surfaces in vitro and to trigger an inflammatory response characterized by spontaneous bleeding, ulceration, soft tissue necrosis, hyperplasia, and implant failure in vivo [25].

Bacterial adhesion to $\mathrm{Ti}$ surfaces is roughnessdependent $[7,12]$, although not significantly influencing plaque composition [7]. Increased roughness provides a larger surface and additional niches for bacterial adhesion, reduces shearing forces, and, as a consequence, reduces the desorption of bacteria during early phases of adhesion [7, 39].

However, since in our study all implants were considered minimally to moderately rough, differences in the percentage of contaminated area may be attributed to surface properties other than roughness, such as surface energy, chemical composition, and wettability. All implants were composed of titanium (Ti), but OT, SLA, and ACQ showed the presence of chemical elements other than $\mathrm{Ti}$, including aluminum, vanadium, sodium, chlorine, and oxygen. Chemical composition of the surface results in different reactions from the surrounding media [40] and is different from the bulk material due to preparation methods and impurities [41].

It has been shown that the chemical composition and surface topography in the macro and micro scales have strong effects on cell behavior [6]. Modifications in the nanoscale level, which can be created by deposition of a material at implant surface or by etching away part of a surface, as observed in some implants investigated in this study, may also influence cell and bacterial behavior [42]. Although the nanotopographic surface is chemically similar to the bulk, the surface itself may induce differences in surface chemistry or energy, such as an increase in hydrophobicity [42]. The strength of cellular adhesion to a nanorough substrate can be predicted by a mathematical model: for small surface energy, increases in surface roughness impairs cell adhesion; in moderate or intermediate surface energy, increases in surface roughness has a minor effect on cell adhesion; and in large surface energy, optimal roughness maximizes cell adhesion [43]. Considering that, surface topography and physico-chemical properties of materials may promote cell adhesion and influence bacterial adhesion [42].

These characteristics may be modified by mechanical and/or chemical treatments performed to detoxify contaminated implant surfaces. Therefore, it is important to determine if moderately rough implants decontaminated by mechanical and chemical methods allows the adhesion of osteoblastic cells, which is essential to reosseointegration. Our findings showed that, despite decontamination procedures, all implants may have presented a remaining contaminated area that may have affected cell adhesion and proliferation, since pristine implants showed higher number of cells attached to the surface after $24 \mathrm{~h}$ and $72 \mathrm{~h}$. Since no differences in the number of attached cells to hydrophobic or hydrophilic 
surfaces were found, it can be assumed that residual contamination impaired cell adhesion and spreading. Bürgers et al. [29] have also shown that decontamination of titanium discs previously contaminated by monocultures of S. epidermidis, S. sanguinis, and C. albicans were only partially effective, except for the use of sodium hypochlorite, which is toxic to patients.

Hydrophilic surfaces tend to enhance the early stages of cell adhesion, proliferation, differentiation, and bone mineralization $[44,45]$, and promote earlier osseointegration as determined by greater bone-to-implant contact at initial stages of osseointegration [46]. Surface energy of an implant, indirectly measured by the liquid-solid contact angle (CA), is therefore related to wettability [47].

In this study, three surfaces were considered as hydrophilic (SLA, ACQ, and CM), and the remaining two (NT and OT) were found to be hydrophobic. ACQ was considered as superhydrophilic, since the angle contact is close to $0^{\circ}$. ACQ showed the less percentage of contaminated area, with significant differences from NT. Rodriguez Y Baena et al. [48] showed significantly less contaminated area in OT and even lesser on NT than on machined implants, especially for A. actinomycetemcomitans, S. mutans, and S. sanguis than for $P$. gingivalis and $S$. salivarius strains. Similar results were described by Lubin et al. [30], who showed that OT discs were easier to decontaminate than NT and that tetracycline and citric acid were the most effective solutions for the disinfection of $P$. gingivalis from OT discs. These findings suggest that different solutions may have different outcomes depending on surface characteristics.

\section{Conclusions}

Only NT and CM implants showed chemical composition by titanium pure. ACQ exhibited hydrophilic behavior while NT and OT hydrophobic properties. The decontaminated implants showed lesser cells adhered during 24 and $72 \mathrm{~h}$ when compared to uncontaminated implants, corresponding respectively to adhesion and proliferation analysis. CM implants showed more cells attached after $24 \mathrm{~h}$ for experimental group. NT implants demonstrated more cell proliferation after $72 \mathrm{~h}$ for control group. Considering that, further preclinical and clinical studies are necessary to determine how different decontamination protocols can affect cell migration and proliferation on implants with different surface treatment, chemistry, surface energy, and wettability.

\section{Abbreviations}

NT: Nanotite; OT: Osseotite; SLA: SLActive; ACQ: Acqua; CM: Neoporos drive Cone Morse; SEM: Scanning electron microscopy; EDS: Energy dispersive Xray spectrometry; WETT: Wettability analysis; Saos-2: Pre-existing human primary osteogenic sarcoma cells; Aa: Aggregatibacter actinomycetemcomitans; EDTA: Ethylenediaminetetraacetic acid; CA: Contact angle

\section{Acknowledgements}

Not applicable.

\section{Authors' contributions}

All authors discussed the results and contributed to the final manuscript: Ísis de Fátima Balderrama performed all analysis, collected the data, and wrote the paper; Matheus Völz Cardoso proposed and performed the in vitro analysis; Vitor Toledo de Stuani performed the analysis and helped shape the paper; Adriana Arruda Matos proposed and performed the cell culture analysis (Saos-2); Rodrigo Cardoso de Oliveira: verified the analyticsal methods and provided critical feedback and helped shape the research; Sebastião Luiz Aguiar Greghi contributed data and analysis tools; Adriana Campos Passanezi Sant'Ana conceived and designed the analysis and idea, verified the analytical methods, and supervised the findings of this work. The author(s) read and approved the final manuscript.

\section{Authors' information}

Not applicable.

\section{Funding}

This work was supported by the Bauru School of Dentistry, University of São Paulo-USP and by Coordination for the Improvement of Higher Education Personnel_CAPES, Brazilian Ministry of Education.

Availability of data and materials

The authors from this work are available to support data.

Ethics approval and consent to participate

Not applicable.

\section{Consent for publication}

All authors are aware for publication of this work.

\section{Competing interests}

Ísis de Fátima Balderrama, Matheus Völz Cardoso, Vitor de Toledo Stuani, Rodrigo Cardoso de Oliveira, Adriana Arruda Matos, Sebastião Luiz Aguiar Greghi, and Adriana Campos Passanezi Sant'Ana declare that they have no competing interests.

\section{Author details}

${ }^{1}$ Department of Diagnosis and Surgery, Araraquara School of Dentistry, Sao Paulo State University, Araraquara, Sao Paulo, Brazil. ${ }^{2}$ Department of Prosthodontics and Periodontics, Bauru School of Dentistry, University of Sao Paulo, Bauru, Sao Paulo, Brazil. ${ }^{3}$ Department of Biological Science, Bauru School of Dentistry, University of Sao Paulo, Bauru, Sao Paulo, Brazil.

Received: 4 July 2020 Accepted: 6 November 2020

Published online: 17 December 2020

\section{References}

1. Bränemark PI, Hansson BO, Adell R, et al. Osseointegrated implants in the treatment of the edentulous jaw. Experience from a 10-year period. Scand J Plast Reconstr Surg. 1977;16:1-132.

2. Albrektsson T, Sennerby L. Direct bone anchorage of oral implants: clinical and experimental considerations of the concept of osseointegration. Int J Prosthodont. 1990;3:30-41.

3. Albrektsson T. Direct bone anchorage of dental implants. J Prosthet Dent. 1983;50:255-61.

4. Buser D, Broggini N, Wieland M, et al. Enhanced bone apposition to a chemically modified SLA titanium surface. J Dent Res. 2004;83:529-33.

5. Wennerberg A, Albrektsson T. Effects of titanium surface topography on bone integration: a systematic review. Clin Oral Implants Res. 2009;20: 172-84.

6. Anselme K. Osteoblast adhesion on biomaterials. Biomaterials. 2000;21:66781.

7. Al-Ahmad A, Wiedmann-Al-Ahmad M, Fackler A, et al. In vivo study of the initial bacterial adhesion on different implant materials. Arch Oral Biol. 2013; 58:1139-47.

8. Mombelli A, van OOsten MA, Schurch E Jr, et al. The microbiota associated with successful or failing osseointegrated titanium implants. Oral Microbiol Immunol. 1987;2:145-51. 
9. Canullo L, Peñarrocha-Oltra D, Covani U, et al. Microbiologic and clinical findings of implants in healthy condition and with peri-implantitis. Int J Oral Maxillofac Implants. 2015;30:834-42.

10. Canullo L, Peñarrocha-Oltra D, Covani U, et al. Clinical and microbiological findings in patients with peri-implantitis: a cross-sectional study. Clin Oral Implants Res. 2016;27(3):376-82

11. Charalampakis G, Belibasakis GN. Microbiome of peri-implant infections: lessons from conventional, molecular and metagenomics analyses. Virulence. 2015;6:183-7.

12. Badhihi Hauslich L, Sela MN, Steinberg D, et al. The adhesion of oral bacteria to modified titanium surfaces: role of plasma proteins and electrostatic forces. Clin Oral Implants Res. 2013;24:49-56.

13. Teughels W, Van Assche N, Sliepen I, et al. Effect of material characteristics and/or surface topography on biofilm development. Clin Oral Implants Res. 2006;17:68-81.

14. Persson LG, Berglundh $T$, Lindhe J, et al. Re-osseointegration after treatment of peri-implantitis at different implant surfaces. An experimental study in the dog. Clin Oral Implants Res. 2001;12:595-603.

15. Lang NP, Berghlundh T, Heitz-Mayfield LJ, et al. Consensus statements and recommended clinical procedures regarding implant survival and complications. Int J Oral Maxillofac Implants. 2004:19:150-4.

16. Lindhe J, Meyle J, Group D of European Workshop on Periodontology. Periimplant diseases: consensus report of the Sixth European Workshop on Periodontology. J Clin Periodontol. 2008;35:282-5.

17. Schwarz F, Sahm N, Iglhaut $G$, et al. Impact of the method of surface debridement and decontamination on the clinical outcome following combined surgical therapy of peri-implantitis: a randomized controlled clinical study. J Clin Periodontol. 2001;38:276-84.

18. Kreisler M, Kohnen W, Christoffers AB, et al. In vitro evaluation of the biocompatibility of contaminated implant surfaces treated with an Er:YAG laser and an air powder system. Clin Oral Implants Res. 2005;16:36-43.

19. Salmeron S, Rezende ML, Consolaro A, et al. Laser therapy as an effective method for implant surface decontamination: a histomorphometric study in rats. J Periodontol. 2013;84:641-9.

20. Mellado-Valero A, Buitrago-Vera P, Solá-Ruiz MF, et al. Decontamination of dental implant surface in peri-implantitis treatment: a literature review. Med Oral Patol Oral Cir Bucal. 2013;18:e869-76.

21. Gosau M, Hahnel S, Schwarz F, et al. Effect of six different peri-implantitis disinfection methods on in vivo human oral biofilm. Clin Oral Implants Res. 2010;21:866-72

22. Valderrama P, Wilson TG Jr. Detoxification of implant surfaces affected by periimplant disease: an overview of surgical methods. Int J Dent. 2013:740-680.

23. Dostie S, Alkadi LT, Owen G, et al. Chemotherapeutic decontamination of dental implants colonized by mature multispecies oral biofilm. J Clin Periodontol. 2017:44:403-9.

24. Strever JM, Lee J, Ealick W, et al. Erbium, Chromium: yttrium-scandiumgallium-garnet laser effectively ablates single-species biofilm on titanium disks without detectable surface damage. J Periodontol. 2017:88:484-92.

25. Freire MO, Sedghizadeh PP, Schaudinn C, et al. Development of an animal model for Aggregatibacter actinomycetemcomtians biofilm-mediated oral osteolytic infection: a preliminary study. J Periodontol. 2011;82:778-89.

26. Derks J, Tomasi C. Peri-implant health and disease. A systematic review of current epidemiology. J Clin Periodontol. 2015;42:S158-71.

27. Renvert S, Quirineyn M. Risk indicators for peri-implantitis: a narrative review. Clin Oral Implants Res. 2015:26:15-44

28. Ungvári K, Pelsöczi IK, Kormos B, et al. Effects of titanium implant surfaces of chemical agents used for the treatment of peri-implantitis. J Biomed Mater Res B: Appl Biomater. 2010;94:222-9.

29. Bürgers R, Witecy C, Hahnel $S$, et al. The effect of various topical periimplantitis antiseptics on Staphylococcus epidermidis, Candida albicans and Streptococcus sanguinis. Arch Oral Biol. 2012;57:940-7.

30. Lubin J, Hernandez MA, Drukteinis SE, et al. Effectiveness of disinfection therapies and promotion of osteoblast growth on osseotite and nanotite implant surfaces. Implant Dent. 2014:23:426-33.

31. Sánchez MC, Llama-Palacios A, Fernández E, et al. An in vitro biofilm model associated to dental implants: structural and quantitative analysis of in vitro biofilm formation on different dental implant surfaces. Dent Mater. 2014;30: 1161-71.

32. Wheelis SE, Gindri IM, Valderrama P, et al. Effects of decontamination solutions on the surface of titanium: investigation of surface morphology, composition and roughness. Clin Oral Implants Res. 2016;27:329-40.
33. Kotsakis GA, Lan C, Barbosa J, et al. Antimicrobial agents used in the treatment of peri-implantitis alter the physicochemistry and cytocompatibility of titanium surfaces. J Periodontol. 2016;87:809-19.

34. Rosa MB, Albrektsson T, Francischone $C E$, et al. Micrometric characterization of the implant surfaces from the five largest companies in Brazil, the second largest worldwide implant market. Int J Oral Maxillofac Implants. 2013;28: 358-65.

35. Leonhardt A, Berglundh T, Ericsson I, et al. Putative periodontal pathogens on titanium implants and teeth in experimental gingivitis and periodontitis in beagle dogs. Clin Oral Implants Res. 1992;3:112-9.

36. Zhuang LF, Watt RM, Mattheos N, et al. Periodontal and peri-implant microbiota in patients with healthy and inflamed periodontal and periimplant tissues. Clin Oral Implants Res. 2016;27:13-21.

37. Van Winkelhoff AJ, Wolf JW. Actinobacillus actinomycetemcomitansassociated peri-implantitis in an edentulous patient. A case report. J Clin Periodontol. 2000;27:531-5.

38. Persson GR, Renvert S. Cluster of bacteria associated with peri-implantitis. Clin Implant Dent Relat Res. 2014;16:783-93.

39. Rimondini $L$, Farè $S$, Brambilla $E$, et al. The effect of surface roughness on early in vivo plaque colonization on titanium. J Periodontol. 1997;68:556-62.

40. Albrektsson T, Wennerberg A. Oral implant surfaces: part 1 - review focusing on topographic and chemical properties of different surfaces and in vivo responses to them. Int J Prosthodont. 2004;17:536-43.

41. Smith DC, Pilliar RM, Metson JB, et al. Dental implant materials. 2. Preparative procedures and surface spectroscopic studies. J Biomed Mater Res. 1992;25:1069-84.

42. Anselme K, Davidson P, Popa AM, et al. The interaction of cells and bacteria with surfaces at the nanometre scale. Acta Biomater. 2010;6:3824-46.

43. Decuzzi P, Ferrari M. Modulating cellular adhesion through nanotopography. Biomaterials. 2010;31:173-9.

44. Eriksson C, Nygren H, Ohlson K. Implantation of hydrophilic and hydrophobic titanium discs in rat tibia: cellular reaction on the surfaces during the first 3 weeks in bone. Biomaterials. 2004:25:4759-66.

45. Bornstein $M M$, Valderrama $P$, Jones $A A$, et al. Bone apposition around two different sandblasted and acid titanium implant surfaces: a histomorphometric study in canine mandibles. Clin Oral Implants Res. 2008; 19:233-41.

46. Lang NP, Salvi GE, Huynh-Ba G, et al. Early osseointegration to hydrophilic and hydrophobic implant surfaces in humans. Clin Oral Impl Res. 2011;22: 349-56.

47. Gittens RA, Scheideler L, Rupp F, Hyzy SL, Geis-Gerstorfer J, Schwartz Z, Boyan $\mathrm{BD}$. A review on the wettability of dental implant surfaces $\mathrm{I}$ : biological and clinical aspects. Acta Biomater. 2014;10:2907-18.

48. Rodriguez y Baena R, Arciola CR, Selan $L$, et al. Evaluation of bacterial adhesion on machined titanium, Osseotite ${ }^{\oplus}$ and Nanotite ${ }^{\circledast}$ discs. Int J Artif Organs. 2012:35:754-61.

\section{Publisher's Note}

Springer Nature remains neutral with regard to jurisdictional claims in published maps and institutional affiliations.

\section{Submit your manuscript to a SpringerOpen ${ }^{\circ}$ journal and benefit from:}

- Convenient online submission

- Rigorous peer review

- Open access: articles freely available online

- High visibility within the field

- Retaining the copyright to your article

Submit your next manuscript at $>$ springeropen.com 